\title{
Antibacterial and Antioxidant Activities of Acetogenins from Streptomyces sp. VE2; An Endophyte in Vernonia cinerea (L.) Less.
}

\author{
Thongchai Taechowisan ${ }^{1 *}$, Chatchadakan Singtotong ${ }^{1}$, Waya S. Phutdhawong ${ }^{2}$ \\ ${ }^{1}$ Department of Microbiology, ${ }^{2}$ Department of Chemistry, Faculty of Science, Silpakorn University, Nakorn Pathom 73000, Thailand.
}

\section{ARTICLE INFO \\ Article history: \\ Received on: 25/04/2016 \\ Revised on: 11/05/2016 \\ Accepted on: 08/06/2016 \\ Available online: 30/08/2016}

Key words:

Acetogenins, antibacterial

activity, antioxidant activity,

Streptomyces sp.

\begin{abstract}
Strain VE2 was isolated from the stem tissue of Vernonia cinerea (L.) Less. and identified as Streptomyces sp. on the basis of morphology, chemotaxonomy and 16SrDNA sequencing. The fractionation of the crude ethyl acetate (CEA) extract from VE2 cultures led to the isolation of two acetogenins; squamocin and rollidecin B; these compounds and CEA extract had potential in antibacterial and antioxidant activities. The crude extract showed the highest activity against Salmonella Typhi ATCC19430 and Bacillus cereus ATCC7064, with MIC values of $32 \mu \mathrm{g} / \mathrm{ml}$. Squamocin also showed the lowest MIC $(32 \mu \mathrm{g} / \mathrm{ml})$ and Minimum Bactericidal Concentration (MBC) $(128 \mu \mathrm{g} / \mathrm{ml})$ against $S$. Typhi and B. cereus with corresponding large diameter of the zone of inhibitions (27.5 and $28.2 \mathrm{~mm}$, respectively). Rollidecin B showed the highest DPPH antioxidant activity with $\mathrm{SC}_{50}$ value of $58.92 \mu \mathrm{g} / \mathrm{ml}$.
\end{abstract}

\section{INTRODUCTION}

Endophytes are microorganisms that colonize inside plant tissue. They live between the living cells of their respective host and cause no overt tissue damage (Azevedo et al., 2001; Zhang et al., 2006; Bandara et al., 2006). They would help to improve the host plant's growth and promotional activity against diseases caused by phytopathogenic fungi (Azevedo et al., 2001). Usually, fungi are the most commonly isolated endophytic microorganisms, but recently the endophytic actinomycetes were isolated from the tissues of healthy plants (Joseph et al., 2012). Some of endophytic actinomycetes can produce important compounds which exhibited various biological activities, such as antimicrobial activity, antioxidant activity, anti-inflammatory activity, etc (Strobel et al., 2003). Since bioactive compounds from endophytic Streptomyces have distinct chemical structures and some of them are novel compounds. In our previous studies, many endophytic Streptomyces were isolated from plant tissues,

* Corresponding Author

Email:tewson84@hotmail.com some of them produced the secondary metabolites against bacteria and phytopathogenic fungi (Taechowisan et al., 2005, 2008, 2012, 2014).

We report here the isolation of the stems of Vernonia cinerea (L.) Less. of another endophytic Streptomyces sp. VE2. The crude ethyl acetate (CEA) extract and purified compounds of Streptomyces sp. VE2 displayed strong antibacterial and antioxidant properties.

\section{MATERIALS AND METHODS}

\section{Organisms and media}

Streptomyces sp. VE2 was isolated from the stem tissues of Vernonia cinerea (L.) Less. by the surface-sterilization technique (Taechowisan et al., 2003). Identification of the isolate to species level was based on morphology, chemotaxonomy and also $16 \mathrm{~S}$ rDNA sequencing as described in our previous study (Taechowisan and Lumyong, 2003).

Solid medium for sporulation used in this study was International Streptomyces Project Medium 4 (ISP-4) and the culture medium used for secondary metabolites production was ISP-2 (Shirling and Gottlieb, 1966). 


\section{Preparation and fractionation of the crude extract}

The 10-day-old cultures on ISP-2 agar (100 Petri dishes) were cut into small pieces and extracted three times with ethyl acetate. This organic solvent was pooled and then taken to dryness under flash evaporation to give a dark brown solid (734 mg). The solid was dissolved in $10 \mathrm{ml}$ of chloroform and fractionated on column chromatography (Merck silica gel 60, 35-70 mesh) with hexane, diethyl ether and methanol. Fractions were monitored by TLC, and spots were visualized by heating silica gel plates sprayed with $10 \% \mathrm{H}_{2} \mathrm{SO}_{4}$ in ethanol. The combined fractions eluted with $50 \%$ diethyl ether in hexane, $100 \%$ diethyl ether, and $5 \%$ methanol in diethyl ether (308 mg) were further separated by MPLC (400 x $40 \mathrm{~mm}$ column, Merck LiChroprep Si 60, 25-40 $\mu \mathrm{m}$, UVdetection, $254 \mathrm{~nm}$ ) to afford fr. A (42 mg), fr. B (68 mg) and fr. C (54 mg). The fr. $\mathrm{A}$ and $\mathrm{C}$ have no activity against tested microorganisms. Final purification of fr. B was achieved by prep TLC (Merck, Si gel 60, $0.5 \mathrm{~mm}$; dichloromethane : diethyl ether = $75: 25)$ to afford compounds 1 (13 $\mathrm{mg}$ ) and 2 (17 mg).

\section{Antimicrobial activity assay}

An in vitro plate assay technique was used to test the inhibitory effects of Streptomyces sp. VE2 on the tested bacteria as described in the previous report (Taechowisan et al., 2008).

For screening of antibacterial activity of the endophytic actinomycetes, we used the solid media bioassay test against Staphylococcus aureus ATCC25932, Bacillus cereus ATCC7064, Bacillus subtilis ATCC6633, Escherichia coli ATCC10536, Salmonella Typhi ATCC19430 and Pseudomonas aeruginosa ATCC27853, these bacteria were cultured in ISP-2 broth at $37^{\circ} \mathrm{C}$ for $24 \mathrm{~h}$. The cells were diluted to $10^{5}$ cells $/ \mathrm{ml}$ in soft agar and then were overlayed on 5 days pre-grown colony of endophytic actinomycetes on ISP-2 plates.

For antibacterial assays, the CEA extract and purified compounds were tested against the tested bacteria using the paper disk method (National Committee for Clinical Laboratory Standards (NCCLS), 1997). Two pieces of 8-mm sterile paper disks (Advantec, Toyo Roshi Kaisha, LTD., Japan) were respectively soaked in crude extract and purified compounds at the amount of $50 \mu \mathrm{g} / \mathrm{disc}$. The air-dried discs were placed on ISP-2 plates. Each plate was then overlayed with top agar containing $10^{5}$ cells $/ \mathrm{ml}$ of bacteria strains. The plates were incubated at $37^{\circ} \mathrm{C}$ for $24 \mathrm{~h}$. The width of inhibition zones was measured. Each treatment consisted of three replicates. The experiment was repeated twice. Ampicillin (30 Unit/disc) and Chloramphenicol (30 $\mu \mathrm{g} / \mathrm{disc})$ (Oxoid, UK) were used as references for antimicrobial activity.

\section{Minimum inhibitory concentrations (MICs)}

MICs of CEA extract and purified compounds were determined by NCCLS microbroth dilution methods (NCCLS, 2000). The agents were dissolved in dimethyl sulfoxide (DMSO). A $10 \mu \mathrm{l}$ of bacterial suspension $\left(10^{5}\right.$ cells $\left./ \mathrm{ml}\right)$ was inoculated into each well of a 96-well microplate, each containing a different concentration of the test agents. We performed doubling dilutions of the test agents. Ampicillin and chloramphenicol were used as references for antibacterial activity. The range of sample dilutions was 512 to $1 \mu \mathrm{g} / \mathrm{ml}$ in nutrient broth supplement with $10 \%$ glucose (NBG) and a final concentration of test agent that inhibited bacterial growth, as indicated by the absence of turbidity. Test agent-free broth containing 5\% DMSO was incubated as growth control. Minimum microbicidal concentration was determined by inoculating on to nutrient agar plates, a $10 \mu \mathrm{l}$ of medium from each of the well from the MIC test which showed no turbidity. The plates were incubated at $37^{\circ} \mathrm{C}$ for $24 \mathrm{~h}$. MMCs were defined as the lowest concentration of test agent where was no microbial growth on the plates.

\section{Radical-scavenging activity - DPPH assay}

The antioxidant activity of the CEA extract and purified compounds was evaluated by monitoring its ability in quenching the stable free radical DPPH, according to a slightly modified method (Choi et al., 2002). Spectrophotometric analysis was used to measure the free radical scavenging capacity and to determine the scavenging concentration $\left(\mathrm{SC}_{50}\right)$ of the CEA extract and purified compounds. The DPPH quenching ability was expressed as $\mathrm{SC}_{50}$ (the concentration required to inhibit radical formation by $50 \%$ ). Six different ethanol dilutions of the CEA extract or each compound $(2.5 \mathrm{ml})$, at $250,125,62.5,31.25,15.62$ and $7.81 \mu \mathrm{g} / \mathrm{ml}$ were mixed with $1.0 \mathrm{ml}$ of a $0.3 \mathrm{mM}$ DPPH ethanol solution. Ethanol $(1.0 \mathrm{ml})$ plus the CEA extract or each compound $(2.5 \mathrm{ml})$ was used as a blank. The absorbance was measured at $518 \mathrm{~nm}$ by UV-VIS spectrophotometer after $30 \mathrm{~min}$ of reaction at room temperature. The radical was prepared daily and protected from light. Relative activities were calculated from the calibration curve of L-ascorbic acid standard solution working in the same experimental conditions. Scavenging capacity in percent (SC\%) was calculated in following way, according to the equation:

$$
\mathrm{SC} \%=100-\left[\left(\mathrm{Abs}_{\text {sample }}-\mathrm{Abs}_{\text {blank }}\right) \times 100 / \mathrm{Abs}_{\text {control }}\right]
$$

Where $\mathrm{Abs}_{\text {sample }}$ is the absorbance of the test compound and $\mathrm{Abs}_{\text {control }}$ is the absorbance of the control reaction (containing all reagents except the test agent). SC\% was plotted against sample concentration, and a linear regression curve was established in order to calculate the $\mathrm{SC}_{50}$. Tests were carried out in triplicate. Correlation coefficients were optimized.

\section{RESULTS}

An endophyte designated Streptomyces sp. VE2 was isolated from the stem tissues of Vernonia cinerea (L.) Less. This strain was of great interest, because of its potent antibacterial and antioxidant activities. Morphological observation of 21-day-old culture of VE2 grown on ISP-2 medium revealed that sporophores were straight to flexuous, producing oval-shaped spores $(1 \times 1.5$ $\mu \mathrm{m})$ with spin surfaces (Figure 1). The substrate mycelium was extensively branched with non-fragmenting hyphae. The aerial mycelium was white changing to brown with yellow soluble pigment occasionally discernible. From the chemotaxonomy study, this strain contained LL-type diaminopimelic acid in the wholecell hydrolysates. Almost the complete $16 \mathrm{~S}$ rDNA sequence was 


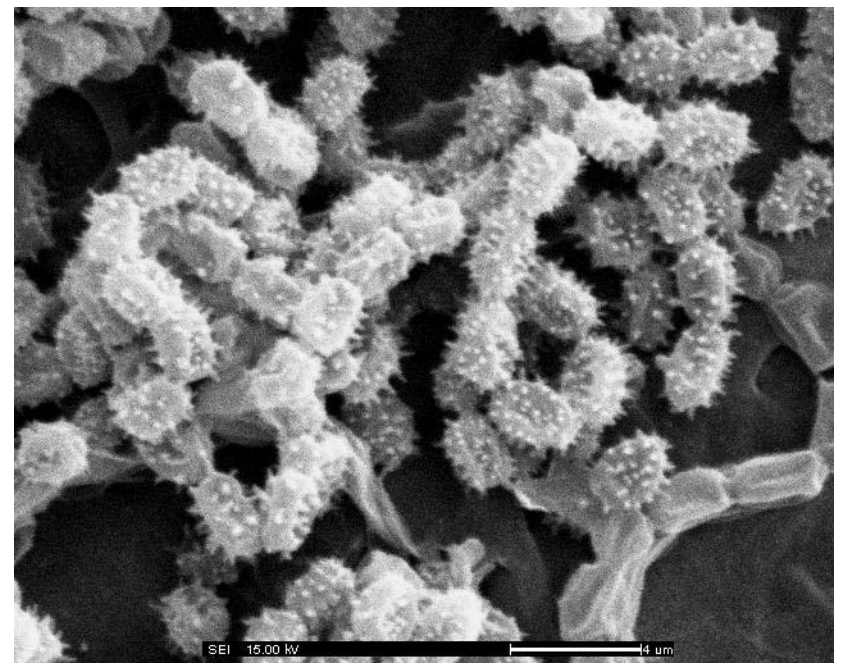

Fig. 1: Scanning electron micrograph showing spore chains and spore surface of Streptomyces sp. VE2. Bar, $4 \mu \mathrm{m}$.

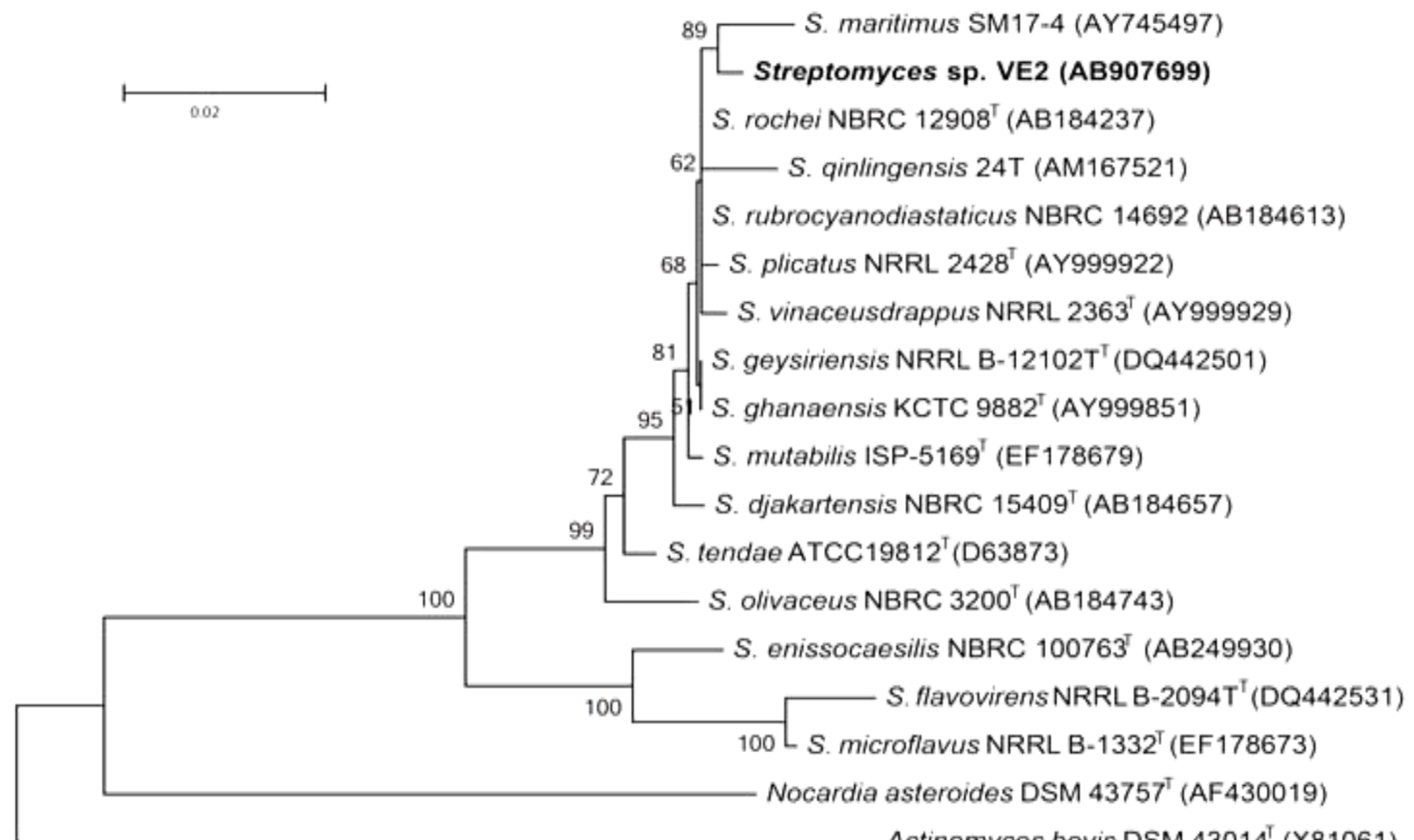

Fig. 2: Neighbor-joining phylogenetic tree of Streptomyces sp. VE2, including representatives of the most closely-related type strains which were retrieved from GenBank, and accession numbers appear in parentheses. Bootstrap (1,000 replicates) values are given in percentage. Bar, 0.01 substitutions per nucleotide.

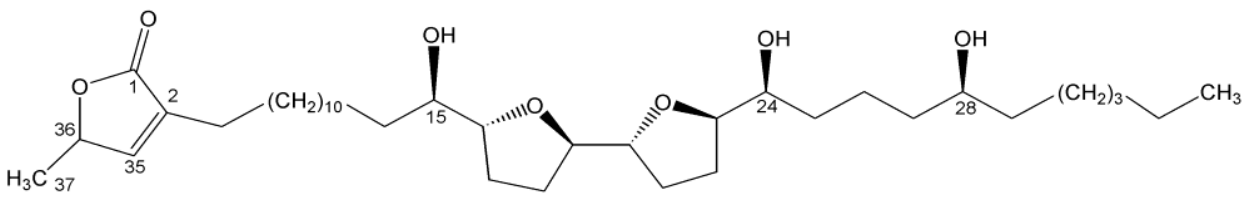

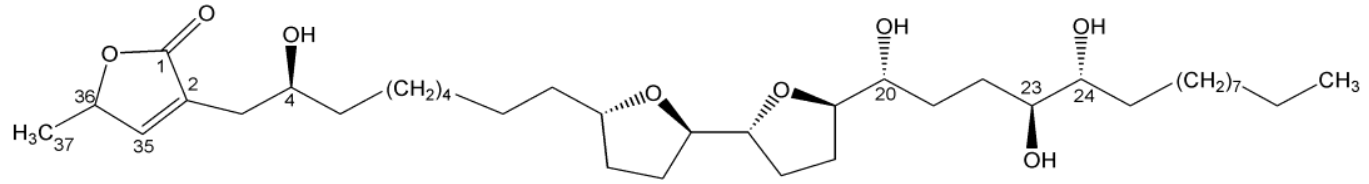

Fig. 3: Chemical structures of Squamocin (1) and Rollidecin B (2). 
determined for the endophytic Streptomyces sp. VE2 from position 27 to position 1423. BLAST search results for strain VE2 came from GenBank; when reference sequences were chosen. The BLAST search results and the phylogenetic tree generated from representative strains of the related genera showed that strain VE2 had high levels of sequence similarity to species of Streptomyces maritimus SM17-4 (accession number: AY745497) (Figure 2). $16 \mathrm{~S}$ rDNA analysis revealed that strain VE2 is phylogenetically closely related to Streptomyces maritimus (the sequence similarity levels were $97.48 \%$ ). The nucleotide sequence data reported in this paper appeared in the GenBank, EMBL and DDBJ databases with accession number AB907699.

Ethyl acetate extract from the strain VE2 was purified by column chromatography. In the active fraction, three compounds were isolated and identified as following.

Compound 1; Squamocin (1): $\mathrm{C}_{37} \mathrm{H}_{66} \mathrm{O}_{7}$; yellowish oil; $[\alpha]_{\mathrm{D}}:+19^{\circ}\left(c 0.23, \mathrm{CHCl}_{3}\right)$. UV (MeOH): $\lambda_{\max }(\log \varepsilon) 210$ (3.88); mp 190-192 ${ }^{\circ} \mathrm{C}$; CIMS: $m / z=623[\mathrm{MH}]^{+}, 605\left[\mathrm{MH}-\mathrm{H}_{2} \mathrm{O}\right]^{+}, 587$ $\left[\mathrm{MH}-2 \mathrm{H}_{2} \mathrm{O}\right]^{+}, 569\left[\mathrm{MH}-3 \mathrm{H}_{2} \mathrm{O}\right]^{+}, 519,501,483,435,417,399$, 347, 329, 295 (100), 267, 239, 169, 111, 97; EIMS: $m / z=417$, 399, 347, 329, 295 (100), 267, 239, 169, 111, 97, 69; ${ }^{1} \mathrm{H}-\mathrm{NMR}$ and ${ }^{13}$ C-NMR (Fujimoto et al., 1994).

Compound 2; Rollidecin B (2): $\mathrm{C}_{37} \mathrm{H}_{66} \mathrm{O}_{8}$; yellowish oil; $[\alpha]_{\mathrm{D}}:+19^{\circ}\left(c 0.23, \mathrm{CHCl}_{3}\right)$. UV $(\mathrm{MeOH}): \lambda_{\max }(\log \varepsilon) 210$ (3.88); mp 190-192 ${ }^{\circ} \mathrm{C}$; CIMS: $m / z=639[\mathrm{MH}]^{+}(100), 621\left[\mathrm{MH}-\mathrm{H}_{2} \mathrm{O}\right]^{+}$, $603\left[\mathrm{MH}-2 \mathrm{H}_{2} \mathrm{O}\right]^{+}, 585\left[\mathrm{MH}-3 \mathrm{H}_{2} \mathrm{O}\right]^{+}, 567\left[\mathrm{MH}-4 \mathrm{H}_{2} \mathrm{O}\right]^{+}, 449,431$, 413, 379, 361, 309, 299, 291, 281, 263, 247, 229, 211, 171, 153, 141, 123, 111, 97; EIMS: $m / z=449,379,309$ (100), 211, 141, 97, 43; ${ }^{1} \mathrm{H}-\mathrm{NMR}$ and ${ }^{13} \mathrm{C}-\mathrm{NMR}$ (Shi et al., 1996). The chemical structures of compound $\mathbf{1}$ and $\mathbf{2}$ were shown in Figure 3.

The CEA extract from the culture of the strain VE2 showed the highest activity against B. cereus $(24.6 \mathrm{~mm})$ and against $S$. Typhi $(25.5 \mathrm{~mm})$ (Table 1). However, this CEA extract showed low activity against $E$. coli $(16.5 \mathrm{~mm})$ and $P$. aeruginosa (15.5 $\mathrm{mm}$ ). The compound $\mathbf{1}$ showed higher activity than compound 2 , it also showed the highest activity against $B$. cereus $(28.2 \mathrm{~mm})$ and against S. Typhi $(27.5 \mathrm{~mm})$.
The compound $\mathbf{2}$ and CEA extract showed activity against all the test microorganisms less than compound $\mathbf{1}$.

A classification based on MIC values proposed by Algiannis et al. (2001), was used for this study. The extract or the compounds with MIC values up to $<512 \mu \mathrm{g} / \mathrm{ml}$ were considered strong inhibitors, $512 \mu \mathrm{g} / \mathrm{ml}$ as moderate inhibitors and those above $512 \mu \mathrm{g} / \mathrm{ml}$ as weak inhibitors. The crude extract and all the compounds showed the MIC values less than $512 \mu \mathrm{g} / \mathrm{ml}$ (excepted compound 2 on $E$. coli and $P$. aeruginosa), therefore the crude extract and compound $\mathbf{1}$ were considered strong inhibitors against all the test microorganisms. The crude extract and compound $\mathbf{1}$ showed the lowest MIC $(32 \mu \mathrm{g} / \mathrm{ml})$ against B. cereus and $S$. Typhi (Table 2). These were followed by the MIC values $(64 \mu \mathrm{g} / \mathrm{ml})$ of the crude extract against $S$. aureus and B. subtilis and compound 1 against $S$. aureus. The compound 2 had high MIC values (512 $\mu \mathrm{g} / \mathrm{ml}$ ) against $E$. coli and $P$. aeruginosa and therefore considered moderate inhibitors. The compound 1 showed the lowest MBC $(128 \mu \mathrm{g} / \mathrm{ml}$ ) against B. cereus and S. Typhi (Table 3) whereas the crude extract had high MBC values $(512 \mu \mathrm{g} / \mathrm{ml})$ for all test microorganisms. The compound $\mathbf{2}$ had no activity in $\mathrm{MBC}$ for all test microorganisms.

The free radical scavenging capacity of the crude extract and purified compounds was assessed by the decolouration of the ethanolic solution of DPPH. In the presence of an active radical scavenger, the absorption vanishes and the resulting decolourization is stoichiometric at a selected range with respect to the degree of reduction. Ethanolic solutions of DPPH served as control and the calibration curve made with L-ascorbic acid was used to compare the activity, as positive control, since this standard antioxidant activity was well established.

Table 4 shows antioxidant activity of the crude extract and isolated compounds. The compound $\mathbf{2}$ is the most active compounds showing $\mathrm{SC}_{50}$ values of $58.92 \mu \mathrm{g} / \mathrm{ml}$, which is comparable to that of a positive control, L-ascorbic acid showing $\mathrm{SC}_{50}$ values of $43.26 \mu \mathrm{g} / \mathrm{ml}$. Comparing results from compound 1 and $\mathbf{2}$ indicated that a greater number of hydroxyl groups increased an antioxidant activity.

Table 1: Diameters of inhibition zones of the crude extract and purified compounds on the test organisms (mm).

\begin{tabular}{|c|c|c|c|c|c|c|}
\hline \multirow{2}{*}{ Test agents } & \multicolumn{6}{|c|}{ Microorganisms } \\
\hline & S.a. ${ }^{a}$ & B.c. & B.s. & E.c. & P.a. & S.T. \\
\hline Crude extract & $19.5 \pm 1.28$ & $24.6 \pm 1.25$ & $20.5 \pm 1.43$ & $18.5 \pm 1.63$ & $17.4 \pm 1.58$ & $25.5 \pm 0.41$ \\
\hline Compound 1 & $20.0 \pm 1.55$ & $28.2 \pm 1.82$ & $21.6 \pm 1.58$ & $22.8 \pm 1.00$ & $20.0 \pm 1.24$ & $27.5 \pm 1.65$ \\
\hline Compound 2 & $18.3 \pm 1.20$ & $19.2 \pm 1.53$ & $20.5 \pm 1.44$ & $15.0 \pm 1.52$ & $11.6 \pm 1.84$ & $17.5 \pm 1.34$ \\
\hline Ampicillin & $31.3 \pm 0.64$ & $27.7 \pm 0.55$ & $26.4 \pm 0.78$ & $27.4 \pm 0.83$ & $24.2 \pm 0.76$ & $26.2 \pm 0.62$ \\
\hline Chloramphenicol & $29.3 \pm 0.82$ & $27.3 \pm 0.65$ & $27.4 \pm 0.88$ & $26.5 \pm 0.72$ & $27.8 \pm 0.44$ & $27.2 \pm 0.54$ \\
\hline
\end{tabular}

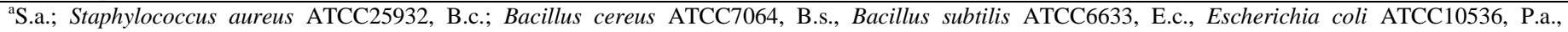
Pseudomonas aeruginosa ATCC27853, and S.T., Salmonella Typhi ATCC19430.

Table 2: Minimum inhibitory concentrations $(\mu \mathrm{g} / \mathrm{ml})$ of the crude extract and isolated compounds.

\begin{tabular}{|c|c|c|c|c|c|c|}
\hline \multirow{2}{*}{ Test agents } & \multicolumn{6}{|c|}{ Microorganisms } \\
\hline & S.a. ${ }^{a}$ & B.c. & B.s. & E.c. & P.a. & S.T. \\
\hline Crude extract & 64 & 32 & 64 & 128 & 256 & 32 \\
\hline Compound 1 & 64 & 32 & 128 & 128 & 256 & 32 \\
\hline Compound 2 & 256 & 256 & 256 & 512 & 512 & 256 \\
\hline Ampicillin & 4 & 4 & 4 & 4 & 4 & 4 \\
\hline Chloramphenicol & 4 & 8 & 8 & 4 & 8 & 4 \\
\hline
\end{tabular}

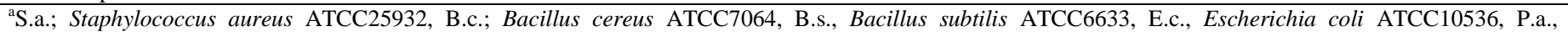
Pseudomonas aeruginosa ATCC27853, and S.T., Salmonella Typhi ATCC19430. 
Table 3: Minimum bactericidal concentrations $(\mu \mathrm{g} / \mathrm{ml})$ of the crude extract and isolated compounds.

\begin{tabular}{|c|c|c|c|c|c|c|}
\hline \multirow{2}{*}{ Test agents } & \multicolumn{6}{|c|}{ Microorganisms } \\
\hline & S.a. ${ }^{a}$ & B.c. & B.s. & E.c. & P.a. & S.T. \\
\hline Crude extract & 512 & 512 & 512 & 512 & 512 & 512 \\
\hline Compound 1 & 256 & 128 & 256 & 256 & 256 & 128 \\
\hline Compound 2 & $>512$ & $>512$ & $>512$ & $>512$ & $>512$ & $>512$ \\
\hline Ampicillin & 16 & 16 & 16 & 32 & 32 & 32 \\
\hline Chloramphenicol & 512 & $>512$ & $>512$ & $>512$ & $>512$ & $>512$ \\
\hline
\end{tabular}

Table 4: Antioxidant activity of the crude extract and isolated compounds.

\begin{tabular}{|c|c|c|}
\hline Test agents & $\operatorname{SC50}(\mu \mathrm{g} / \mathrm{ml})^{\mathrm{a}}$ & Standard deviation \\
\hline Crude extract & 124.62 & 9.54 \\
\hline Compound 1 & 86.76 & 8.25 \\
\hline Compound 2 & 58.92 & 6.70 \\
\hline L-ascorbic acid & 43.26 & 3.68 \\
\hline
\end{tabular}

${ }^{\mathrm{a} C}$ Concentration required to inhibit radical formation by $50 \%$.

\section{DISCUSSION}

The strain VE2 was recovered from the stem tissues of Vernonia cinerea (L.) Less.; a medicinal plant contained several compounds for example: alkaloids, glycosides, steroids and triterpinoids (Misra et al., 1984; Haque et al., 2012; Dhanalakshmi et al., 2013). This bacterium produced yellow soluble pigment after inoculation on to ISP-2 medium for 5 days. Based on results in morphological observation as well as on the presence of LLtype diaminopimelic acid in the whole-cell extracts and 16S rDNA sequence, the endophytic actinomycetes VE2 was identified as belonging to the genus Streptomyces.

The high bioactivity of the CEA extract of the strain VE2 showed by its low MIC (32 $\mu \mathrm{g} / \mathrm{ml})$ against B. cereus and S. Typhi, followed by $S$. aureus and B. subtitis $(64 \mu \mathrm{g} / \mathrm{ml})$ and E. coli $(128$ $\mu \mathrm{g} / \mathrm{ml})$. Notably, antibacterial activity of the crude extract and compounds possessed antibacterial activity less than ampicillin and chloramphenicol.

Two compounds were isolated from the CEA extract of the strain VE2, those were classified as acetogenins. Normally, acetogenins have been isolated from several genera of Annonaceae plants for example Annona squamosa L. (Fujimoto et al., 1994), Uvaria narum Wall. (Hisham et al., 1991) and Rollinia mucosa (Jacq.) Baill. (Shi et al., 1996). Acetogenins have been described as antiprotozoal, insecticides, antimitotic, cytotoxic, fungicides and pesticides compounds (Gonzalez et al., 1997; Cavé et al., 1996). In our study, two acetogenins, Squamocin (compound 1) and Rollidecin B (compound 2) was obtained from the culture of Streptomyces sp. VE2, isolated from the stem tissue of Vernonia cinerea (L.) Less. It proved that Squamocin and Rollidecin B from Streptomyces sp. VE2 were all inhibitory to tested bacteria. In addition, Squamocin, the presence of free hydroxyl group at C-15 to be more essential for antibacterial activity than Rollidecin B. whereas Rollidecin B, the presence of four free hydroxyl group was associated with antioxidant activity of the compound. A previous study on the antioxidant activity of Acetogenins, also indicated that more hydroxyl group on the molecules was crucial for their antioxidant activity (Santos et al., 2010).

\section{CONCLUSION}

This work shows the antibacterial and antioxidant activities of Squamocin and Rollidecin B isolated from the culture of Streptomyces sp. VE2, an endophyte in Vernonia cinerea (L.) Less. Since Squamocin and Rollidecin B have antagonism against tested bacteria. They should be further studied in clinical isolates. The other biological activities of Squamocin and Rollidecin B should be studied as well.

\section{ACKNOWLEDGEMENTS}

This work was supported by Faculty of Science, Silpakorn University, Thailand. The authors are grateful to $\mathrm{Mr}$ Y.N. He and Ms H.L. Liang in Kunming Institute of Botany, The Chinese Academy of Sciences, China for measuring NMR and MS data, respectively.

\section{REFERENCES}

Aligiannis, N., Kalpoutzakis, E., Mitaku, S., Chinou, I.B. Composition and antimicrobial activity of essential oils of two origanum species. Journal of Agricultural Food Chemistry 2001; 40: 4168-4170.

Azevedo, J.L., Maccheroni, W., Pereira, J.O. Endophytic microorganisms: a review on insect control and recent advances on tropical plants. Electron Journal of Biotechnology 2000; 3: 1-36.

Bandara, W.M.M.S., Seneviratne, G., Kulasooriya, S.A. Interactions among endophytic bacteria and fungi: effects and potentials Journal of Bioscience 2006; 31: 645-650.

Cavé, A., Rigadre, B., Laurens, A., Cortes, D. Acetogenins from Annonaceae; In Progress in the Chemistry of Organic Natural Products. (Herz W., ed.). The Florida State University: Tallahassee. 1996; 70: 81288.

Choi, C.W., Kim, S.C., Hwang, S.S., Choi, B.K., Ahn, H.J., Lee, M.Y., Park, S.H., Kim, S.K. Antioxidant activity and free radical scavenging capacity between Korean medicinal plants and flavonoids by assay-guided comparison. Plant Science 2002; 163: 1161- 1168.

Dhanalakshmi, P., Priya, A.J.P., Sagadevan, E., Lakshmi, Y.S., Manimaran, A., Sindhu, S., Arumugam, P. Evaluation of inhibitory effect of Vernonia cenerea L. Leaf extracts on different fungal species. International Journal of Pharmacy and Pharmaceutical Sciences 2013; 5: 414-416.

Fujimoto, Y., Murasaki, C., Shimada, H., Nishioka, S., Kakinuma, K., Singh, S., Singh, M., Gupta, K.Y., Sahai, M. Annonaceous 
acetogenins from the seeds of Annona squamosa. Non-adjacent bistetrahydrofuranic acetogenins. Chemical and Pharmaceutical Bulletin 1994; 42: 1175-1184.

Gonzalez, M.C., Tormo, J.R., Bermejo, A., Zafra-Polo, M.C., Estornell, E., Cortes, D. Rollimembrin, a novel acetogenin inhibitor of mammalian mitochondrial complex-I. Bioorganic and Medicinal Chemistry Letters 1997; 7: 1113-1118.

Haque, A., Hassan, M., Das, A., Begum, B., Ali, Y., Morshed, H. Phytochemical inestigation of Vernonia cinerea (Family: Asteraceae). Journal of Applied Pharmaceutical Science 2012; 2: 79-83.

Hisham, A., Pieters, L.A.C., Claeys, M., Esmans, E., Dommisse, R., Vlietinck, A.J. Squamocin-28-one and Panalicin, two acetogenins from Uvaria Narum. Phytochemistry 1991; 30: 545-548.

Joseph, B., Sankarganesh, P., Edwin, B.T., Raj, S.J. Endophytic Streptomycetes from plants with novel green chemistry: review. International Journal of Biological Chemistry 2012; 6: 42-52.

Misra, T.N., Singh, R.S., Upadhyay, J., Srivastava, R. Chemical constituents of Vernonia cinerea. Isolation and structure elucidation of a new pentacyclic triterpenoid. Journal of Natural Products. 1984; 47: 865867.

National Committee for Clinical Laboratory Standards. Methods for dilution antimicrobial susceptibility tests for bacteria that grow aerobically. Approved standard M7-A5. National Committee for Clinical Laboratory Standards, Wayne, PA, USA; 2000.

National Committee for Clinical Laboratory Standards. Performance standards for antimicrobial disk susceptibility tests. Approved standard M2-A6. National Committee for Clinical Laboratory Standards, Wayne, PA, USA; 1997.

Santos, L.A.R., Pimenta, L.P.S. Boaventura, M.A.D. Acetogenins from Annona cornifolia and their antioxidant capacity. Food Chemistry 2010; 122: 1129-1138.

Shi, G., Gu, Z.M., He, K., Wood, K.V., Zeng, L., Ye, Q., MacDougal, J.M., McLaughlin, J.L. Applying Mosher's method to acetogenins bearing vicinal diols. The absolute configurations of Muricatetrocin $\mathrm{C}$ and Rollidecins $\mathrm{A}$ and $\mathrm{B}$, new bioactive acetogenins from Rollinia mисоsa. Bioorganic and Medicinal Chemistry 1996; 4: 1281-1286.

Shirling, EB, Gottlieb, D. Methods for characterization of Streptomyces species. International Journal of Systematic Bacteriology 1966; 16: 313-340.
Strobel, G., Daisy, B. Bioprospecting for microbial endophytes and their natural products. Microbiologogy and Molecular Biology Reviews 2003; 67: 491-502.

Taechowisan, T., Chanaphat, S., Ruensamran, W., Phutdawong, W.S. Antibacterial activity of new flavonoids from Streptomyces sp. BT01; an endophyte in Boesenbergia rotunda (L.) Mansf. Journal of Applied Pharmaceutical Science 2014; 4: 8-13.

Taechowisan, T., Chanaphat, S., Ruensamran, W., Phutdhawong, W.S. Antifungal activity of 3-methylcarbazoles from Streptomyces sp. LJK109; an endophyte in Alpinia galanga. Journal of Applied Pharmaceutical Science 2012; 2: 124-128.

Taechowisan, T., Chuaychot, N., Chanaphat, S., Wanbanjob, A., Shen, Y. Biological activity of chemical constituents isolated from Streptomyces sp. Tc052, an endophyte in Alpinia galanga. International Journal of Pharmacology 2008; 4: 95-101.

Taechowisan, T., Lu, C., Shen, Y., Lumyong, S. 4arylcoumarins from endophytic Streptomyces aureofaciens CMUAc130 and their antifungal activity. Annals of Microbiology 2005; 55: 63-66.

Taechowisan, T, Peberdy, J.F., Lumyong, S. Isolation of endophytic actinomycetes from selected plants and their antifungal activity. World Journal of Microbiology and Biotechnology 2003; 19: 381385 .

Taechowisan, T., Lumyong, S. Activity of endophytics actinomycetes from roots of Zingiber officinale and Alpinia galanga against phytopathogenic fungi. Annals of Microbiology 2003; 53: 291298.

Zhang, W., Backer, D., Cheng, Q. A Mini-Review of Recent W.O. Patents (2004-2005) of Novel Anti-fungal Compounds in the Field of Anti-infective Drug Targets. Recent Patents on Anti-Infective Drug Discovery 2006; 1: 225-230.

\section{How to cite this article:}

Taechowisan T., Singtotong C., Phutdhawong WS. Antibacterial and Antioxidant Activities of Acetogenins from Streptomyces sp. VE2; An Endophyte in Vernonia cinerea (L.) Less. J App Pharm Sci, 2016; 6 (08): 067-072. 